\title{
Loss of Putting Greens-grade Fertilizer Granules Due to Mowing
}

\author{
Charles F. Mancino' ${ }^{1}$, Dianne Petrunak, and Douglas Wilkinson \\ Department of Agronomy, The Pennsylvania State University, University \\ Park, PA 16802
}

Additional index words. fertilizer fate, turfgrass, potassium, nitrogen

\begin{abstract}
The loss of fertilizer granules collected in turf clippings during routine putting green mowing has not been determined. The objective of this study was to quantify the amounts of greens-grade granular potassium $(\mathrm{K})$ and nitrogen $(\mathrm{N})$ fertilizers collected during the routine mowing of a 'Pennlinks' creeping bentgrass (Agrostis palustris Huds.) putting green. In the first study, five $\mathrm{K}$-containing granular fertilizers were applied at $\mathrm{K}$ rates of 2.43 and $4.86 \mathrm{~g} \cdot \mathrm{m}^{-2}$. A second study was also performed with six granular $\mathrm{N}$ containing fertilizers and one liquid $N$ fertilizer applied at an $N$ rate of $4.86 \mathrm{~g} \cdot \mathrm{m}^{-2}$. Both studies were performed twice. Irrigation $(6.4 \mathrm{~mm})$ was applied immediately after each fertilizer application and again on the following day. These two irrigations, plus additional irrigation and rain, resulted in each study receiving about $2.54 \mathrm{~cm}$ of water over each nineday study period. Mowing and clipping collection using a walk-behind greens mower set to cut at $3.96 \mathrm{~mm}$ began two days after treatment (2 DAT) and continued until 9 DAT. The clippings were oven-dried and separated from the fertilizer using a small pneumatic seed cleaner. Collected fertilizer was weighed and expressed as a percentage of the fertilizer applied. Liquid $\mathbf{N}$ fertilizer loss was estimated to be the difference between clipping $\mathbf{N}$ content of treated plots and untreated controls. Total $\mathrm{K}$ fertilizer loss was: UHS Signature 15-0-30 (15.3\% to 22.9\%) > Lebanon Isotek 11-3-22 (8.7\% to 10.7\%) > Scott's Contec 132-26 (4.9\% to 7.4\%) > Lesco Matrix 12-0-22 (0.1\% to 0.4\%) = Lesco Matrix 5-0-28 $(0.1 \%$ to $0.5 \%$ ). Signature was the only fertilizer significantly affected by rate and a greater percentage of loss occurred at the lower $\mathrm{K}$ application rate. Most loss occurred during the first and second mowing events with small amounts of fertilizer found in clippings from later mowings. The two Lesco materials were not found in clippings after the first mowing. Nitrogen fertilizer granule loss was also greatest with the first and second mowings. Total percentage of losses were IBDU 31-0-0 (75.4\%) > Polyon 41-0-0 (70.8\%) > Milorganite 62-0 $(55.7 \%)>$ Nutralene 40-0-0 $(47.0 \%)>$ UHS Signature $(19.3 \%)>$ Isotek 11-3-22 $(9.5 \%)>$ N-Sure Pro 30-0-0 (1.9\%). In both studies, fertilizer loss appeared to be most related to water-solubility of the fertilizer, but size and density might also be factors.
\end{abstract}

Granular fertilizers are routinely used in golf course putting green establishment and maintenance. Smaller granules have been developed in order to improve the uniformity of the fertilizer application and to aid in moving the fertilizer into the turf canopy. Typically, greens-grade granules are between 0.5 and $1.4 \mathrm{~mm}$ in diameter, with a small percentage of the fertilizer $<0.5 \mathrm{~mm}$ and $>1.4 \mathrm{~mm}$. However, despite their small size, it is often observed that fertilizer granules remain on the turf canopy surface after application and that some fertilizer is removed along with turf clippings during mowing. General recommendations made to reduce mowing loss of granular fertilizers include: 1) irrigation; 2) application of the fertilizer just after mowing; 3) skipping of mowing the day after

\footnotetext{
Received for publication 30 Mar. 2000. Accepted for publication 12 Feb. 2001. Research partially supported by Lesco, Inc., Lebanon Turf Products, and Tessenderlo-Kerley. The cost of publishing this paper was defrayed in part by the payment of page charges. Under postal regulations, this paper therefore must be hereby marked advertisement solely to indicate this fact.

${ }^{1}$ To whom requests for reprints should be addressed. Current address: The Scotts Company, 14111 Scottslawn Road, Marysville, $\mathrm{OH}$ 43041. E-mail address: charles.mancino@scottsco.com
}

lost along with clippings during routine putting green mowing.

\section{Materials and Methods}

Two mowing loss studies, one containing potassium $(\mathrm{K})$ fertilizers and one containing nitrogen $(\mathrm{N})$ fertilizers, were conducted at the Joseph Valentine Turfgrass Research Facility at The Pennsylvania State Univ., Univ. Park, in 1999. Preliminary studies in 1998 determined mowing and irrigation strategies, the approximate number of mowing days required until fertilizer was no longer recovered by the mower, and the use of a small seed cleaner to separate granular fertilizers from oven-dried clippings (Mancino and Hornstein, 1998). In 1999 , the studies were conducted on a sandbased, established 'Pennlinks' creeping bentgrass putting green. The site was uniform, had good turf density, and $100 \%$ groundcover. 'Pennlinks' creeping bentgrass is slightly higher in summer density than 'Penncross' creeping bentgrass (NTEP, 2000). Turf was maintained at a mowing height of $3.97 \mathrm{~mm}$. Prior to research initiation, the turf was mowed five times per week (Monday through Friday), and fertilized and irrigated as needed to maintain an acceptable putting green playing surface.

The $\mathrm{K}$ and $\mathrm{N}$ fertilizers used in this study are shown in Tables 1 and 2. Each fertilizer is recommended for use on putting greens and other low-cut turf. Three 200-g samples of each granular fertilizer were sieved using a 2.8 $\mathrm{mm}, 2 \mathrm{~mm}, 1.4 \mathrm{~mm}, 1 \mathrm{~mm}, 0.5 \mathrm{~mm},<0.50 \mathrm{~mm}$, and pan for particle size analysis. The uniformity coefficient $\left(\mathrm{d}_{60} / \mathrm{d}_{10}\right)$ and Blake's fineness modulus (a measure of the materials coarseness) of each fertilizer was determined as specified by the U.S. Golf Association (1993) for a sand topdressing. This was done in order to compare the size characteristics of the granular fertilizers with those of acceptable topdressing sand that would be expected to fall down into the putting green turf canopy. All the granular $\mathrm{K}$ fertilizers had acceptable sand topdressing uniformity coefficients of $<4.0$, but only the two Lesco materials had fineness modulus values low enough to pass Blake's topdressing fineness parameter of <2.5 (1980) (Tables 1 and 2). Lebanon Isotek, although the most uniform material used in either study, was the coarsest material tested. All of the granular $\mathrm{N}$ fertilizers had acceptable uniformity coefficients with Isotek and IBDU being most uniform (Table 2). The bulk density of three samples of each granular fertilizer was determined by filling cylinders $(5.0 \times 7.6 \mathrm{~cm})$ with fertilizer, tapping the samples lightly on the palm of the hand to settle the samples, recording the height and weight of each sample in the cylinder, and calculating bulk density $\left(\mathrm{g} \cdot \mathrm{cm}^{-3}\right)$. The two Lesco fertilizers had the highest and lowest bulk densities in the $\mathrm{K}$ study (Table 1). UHS Signature and IBDU had the highest and lowest bulk densities, respectively, in the $\mathrm{N}$ study (Table 2).

The first run of each study was initiated on 30 June 1999, when the putting green was mowed and the fertilizer treatments applied. 
Table 1. Sieve analysis, uniformity coefficients $\left(\mathrm{D}_{60} / \mathrm{D}_{10}\right)$, fineness modulus (Blake, 1980), water-solubility, and bulk density of greens-grade K-containing granular fertilizers used in the potassium $(\mathrm{K})$ study.

\begin{tabular}{|c|c|c|c|c|c|c|c|c|c|c|c|c|}
\hline \multirow[b]{2}{*}{ Fertilizer } & \multirow{2}{*}{$\begin{array}{r}\mathrm{K}_{2} \mathrm{O} \\
(\%) \\
\end{array}$} & \multicolumn{6}{|c|}{ Sieve size $(\mathrm{mm})$} & \multirow[b]{2}{*}{$\mathrm{UC}^{\mathrm{z}}$} & \multirow[b]{2}{*}{$\mathrm{FM}^{\mathrm{y}}$} & \multirow{2}{*}{$\begin{array}{l}\mathrm{WS}^{\mathrm{x}} \\
(\%)\end{array}$} & \multirow[b]{2}{*}{ B.D. ${ }^{w}$} & \multirow[b]{2}{*}{ Manufacturer } \\
\hline & & $<0.5$ & 0.5 & 1 & 1.4 & 2 & 2.8 & & & & & \\
\hline & & --- & -- & $\%$ retai & d) - & -- & -- & & & & $\left(\mathrm{g} \cdot \mathrm{cm}^{-3}\right)$ & \\
\hline Lesco Matrix 1 & 28 & 12.8 & 70.4 & 16.4 & 0.4 & 0.0 & 0.0 & 1.96 & 2.78 & 86 & 1.17 & Lesco, Rocky River, Ohio \\
\hline Lesco Matrix 2 & 22 & 24.0 & 61.2 & 14.0 & 0.8 & 0.0 & 0.0 & 2.00 & 2.54 & 79 & 0.99 & Lesco, Rocky River, Ohio \\
\hline Scotts Contec & 26 & 0.4 & 57.2 & 40.0 & 2.0 & 0.0 & 0.0 & 1.70 & 3.07 & 45 & 1.02 & The Scott's Co., Marysville, Ohio \\
\hline Lebanon Isotek & 22 & 0.4 & 9.6 & 36.8 & 46.0 & 7.2 & 0.0 & 1.45 & 3.72 & 66 & 1.01 & Lebanon Seaboard Corp., Lebanon, Pa. \\
\hline UHS Signature & 30 & 5.6 & 65.2 & 26.8 & 1.6 & 0.0 & 0.0 & 1.80 & 2.87 & 50 & 1.12 & United Horticultural Supply, Denver, Colo. \\
\hline
\end{tabular}

${ }^{2}$ Uniformity coefficients $<4.0$ considered acceptable for golf green topdressing materials.

${ }^{y}$ Fineness modulus values 1.7-2.5 considered acceptable for golf green topdressing materials.

${ }^{x}$ Percentage of water-soluble fertilizer after shaking $10 \mathrm{~g}$ material for $1 \mathrm{~min}$ in $75 \mathrm{~mL} 21{ }^{\circ} \mathrm{C}$ tapwater.

${ }^{\mathrm{w}}$ B.D. = bulk density.

Table 2. Sieve analysis, uniformity coefficient $\left(\mathrm{D}_{60} / \mathrm{D}_{10}\right)$, fineness modulus (Blake, 1980), water-solubility, and bulk density of greens-grade $\mathrm{N}$-containing granular fertilizers used in the nitrogen study. N-Sure Pro is a liquid N source.

\begin{tabular}{|c|c|c|c|c|c|c|c|c|c|c|c|c|}
\hline \multirow[b]{2}{*}{ Fertilizer } & \multirow{2}{*}{$\begin{array}{l}\mathrm{N} \\
(\%)\end{array}$} & \multicolumn{6}{|c|}{ Sieve size $(\mathrm{mm})$} & \multirow[b]{2}{*}{$\mathrm{UC}^{\mathrm{z}}$} & \multirow[b]{2}{*}{$\mathrm{FM}^{\mathrm{y}}$} & \multirow{2}{*}{$\begin{array}{l}\mathrm{WS}^{\mathrm{x}} \\
(\%)\end{array}$} & \multirow[b]{2}{*}{ B.D. ${ }^{w}$} & \multirow[b]{2}{*}{ Manufacturer } \\
\hline & & $<0.5$ & 0.5 & 1 & 1.4 & 2 & 2.8 & & & & & \\
\hline & & --- & -- & $\%$ retai & ed) - & -- & -- & & & & $\left(\mathrm{g} \cdot \mathrm{cm}^{-3}\right)$ & \\
\hline Polyon & 41 & 2.4 & 50.8 & 42.8 & 5.2 & 0.0 & 0.0 & 1.66 & 3.11 & 0.0 & 0.79 & Pursell Industries, Sylacauga, AL \\
\hline Milorganite & 6 & 1.2 & 58.8 & 39.6 & 0.0 & 0.0 & 0.0 & 1.72 & 2.95 & 6.0 & 0.87 & $\begin{array}{c}\text { Milwaukee Municipal Sewage Sludge } \\
\text { District, Milwaukee, WI }\end{array}$ \\
\hline IBDU & 31 & 1.2 & 79.2 & 19.2 & 0.0 & 0.0 & 0.0 & 1.55 & 2.89 & 4.0 & 0.72 & IMC Vigoro, Winter Haven, FL \\
\hline Nutralene & 40 & 1.2 & 58.0 & 40.4 & 0.0 & 0.0 & 0.0 & 1.81 & 2.99 & 32.0 & 0.80 & The Andersons, Inc., Maumee, $\mathrm{OH}$ \\
\hline UHS Signature & 15 & 5.6 & 65.2 & 26.8 & 1.6 & 0.0 & 0.0 & 1.80 & 2.87 & 50.0 & 1.12 & United Horticultural Supply, Denver, CO \\
\hline Isotek & 11 & 0.4 & 9.6 & 36.8 & 46.0 & 7.2 & 0.0 & 1.45 & 3.72 & 66.0 & 0.95 & Lebanon Seaboard Corp., Lebanon, PA \\
\hline N-Sure Pro & 30 & --- & --- & --- & --- & --- & --- & --- & --- & --- & & Tessenderlo Kerley, Phoenix, AZ \\
\hline
\end{tabular}

${ }^{\mathrm{z}}$ Uniformity coefficients $<4.0$ considered acceptable for golf green topdressing materials.

${ }^{y}$ Fineness modulus values of 1.7-2.5 considered acceptable for golf green topdressing materials.

${ }^{x}$ Percentage of water-soluble fertilizer after shaking $10 \mathrm{~g}$ material for $1 \mathrm{~min}$ in $75 \mathrm{~mL} 21{ }^{\circ} \mathrm{C}$ tapwater.

${ }^{\mathrm{w}}$ B.D. = bulk density.

Granular $\mathrm{K}$ treatments were applied at two typical $\mathrm{K}$ rates, 2.48 and $4.96 \mathrm{~g} \cdot \mathrm{cm}^{-2}$. The $\mathrm{N}$ fertilizers were applied at the common $\mathrm{N}$ rate of $4.96 \mathrm{~g} \cdot \mathrm{cm}^{-2}$. Granular fertilizers were applied using a small shaker jar with a perforated lid. The liquid $\mathrm{N}$ fertilizer, $\mathrm{N}$-Sure Pro, was applied with a $\mathrm{CO}_{2}$-powered boom sprayer mounted on bicycle wheels. Sprayer pressure and volume were $276 \mathrm{kPa}$ and $81.5 \mathrm{~mL} \cdot \mathrm{m}^{-2}$, respectively. The liquid $\mathrm{N}$ treatment was allowed to dry on the turfgrass foliage $(\approx 0.5 \mathrm{~h})$ before irrigation was applied to the green. The $\mathrm{N}$ fertilizer experiment included untreated controls.

Following fertilizer application, turf was irrigated with $6.4 \mathrm{~mm}$ of water over a period of $\approx 0.25 \mathrm{~h}$. A second $6.4 \mathrm{~mm}$ irrigation was applied the day after treatment (DAT) and mowing was skipped. Routine mowing and clipping collection began on 2 DAT (2 July) and continued until 9 DAT (9 July). Preliminary work with various $\mathrm{N}$ fertilizers had shown that very little to no fertilizer was collected with clippings by this time. Normal turfgrass mowing and irrigation practices were resumed following the 9 DAT clipping collection and continued until 14 July 1999, when the second run of the study was initiated. Clipping collection for the second run began on 16 July (2 DAT) and concluded 23 July (9 DAT).

Clippings were collected with a 12-blade West Point walk-behind greens mower (West Point, PA) set to cut at $3.97 \mathrm{~mm}$. Travel speed was $\approx 3.65 \mathrm{~km} \cdot \mathrm{h}^{-1}$. Clippings from each plot were bagged and oven-dried at $60^{\circ} \mathrm{C}$ for $48 \mathrm{~h}$. Fertilizer granules were removed from clippings with a small pneumatic seed cleaner (New Brunswick General Sheet Metal Works
Seed Blower, model 1070-1; New Brunswick, N.J.) having a variable speed fan that could be adjusted to only remove dry clippings from the sample. The fertilizer granules, which remained in the seed blower, were collected and weighed. Percentage of loss was calculated as: (weight of granules collected/weight of granules applied) $\times 100$. Preliminary work had shown a fertilizer recovery rate of $>95 \%$.

Clippings from liquid $\mathrm{N}$ treated plots and untreated controls in the $\mathrm{N}$ study were ovendried, weighed, and ground to pass a 40-mesh screen using a Thomas-Wiley mill (model 3383-L10; Philadelphia). The ground samples were analyzed for total $\mathrm{N}$ at The Pennsylvania State Agricultural Analytical Services Laboratory (Univ. Park, Pa.) using the Dumas dry-combustion method (Tabatabai, M.A. and J.M. Bremner, 1991). Liquid N loss on collected clippings was estimated to be the difference between the $\mathrm{N}$ content of treated plot clippings and clippings from the untreated controls. This loss could be an overestimation of mowing loss because some of the liquid fertilizer $\mathrm{N}$ could actually have been inside the leaf tissue rather than on its surface.

In addition to irrigation applied following treatment application and 1 DAT, irrigation $(6.4 \mathrm{~mm})$ was also applied on 6 July (6 DAT), and 8 July (8 DAT) in the first run of each study in order to prevent drought stress. Although no additional irrigation was applied during the second run, rain fell on 19 July (<2.5 mm; 5 DAT), 21 July (12.7 mm; 7 DAT), and 22 July (7.62 mm; 8 DAT). In effect, both studies received $\approx 25.4 \mathrm{~mm}$ of water over each 9 d clipping collection period.
Individual treatment plots were $0.9 \times 2.4 \mathrm{~m}$ each with four replications per treatment. The $\mathrm{K}$ study was a two-way factorial design (fertilizer and rate) arranged in a randomized complete block (RCB) with the study repeated twice. The $\mathrm{N}$ study was a one-way factorial design arranged as a RCB design with the study repeated twice. Percentage of K fertilizer loss data were square root transformed before statistical analysis because losses were $<30 \%$, while arc sine transformation was used in the $\mathrm{N}$ loss study because losses ranged from $0 \%$ to almost $75 \%$ (Gomez and Gomez, 1984). Within each study, Levene's test for homogeneity of variance was used to compare the daily and total loss data from each run to determine if data could be combined into a single analysis (Minitab, 2000). Analysis of variance (ANOVA) was then performed on daily and total loss data using SAS Proc ANOVA to test for significant fertilizer, rate, and fertilizer $\times$ rate interactions (SAS Institute, 1994). Separation of means was performed with the $\mathrm{SAS} \mathrm{LSD}_{(P=0.05)}$ procedure.

\section{Results}

Potassium fertilizer loss. Data from the two runs of the $\mathrm{K}$ study were not pooled because Levene's test revealed nonhomogeneity of variance on five of eight sampling days (Table 3). Significant fertilizer, rate, and fertilizer $\times$ rate interactions were also found to occur within each run (Table 3 ).

The greatest amount of daily granular fertilizer loss occurred with the first and second mowing (2DAT and 3 DAT) of each study run 
Table 3. Percentage of applied greens-grade K-containing fertilizer granules lost due to the mowing of a 'Pennlinks' creeping bentgrass putting green. Fertilizers were applied on 30 June (Run 1) and 14 July 1999 (Run 2).

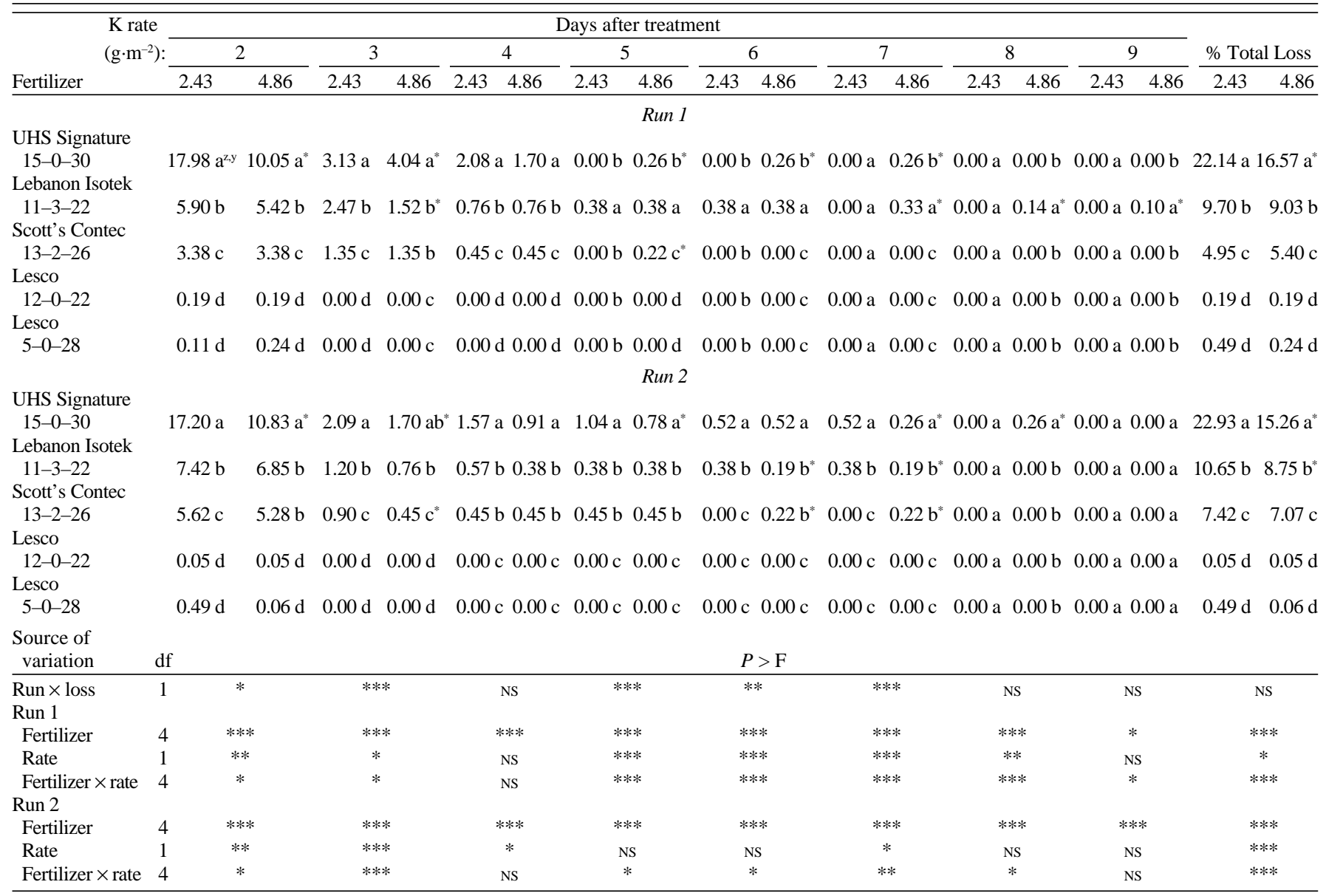

${ }^{2}$ Percentage data square root transformed prior to statistical analysis. Mean separation down a column and within a run by LSD, $P \leq 0.05$. $\mathrm{n}=4$.

${ }^{\mathrm{y}}$ Numbers across columns within fertilizer and day followed by asterisk are significantly different by LSD, $<0.05$. $\mathrm{n}=4$.

Ns, ${ }^{*}, *, * * *$ Nonsignificant or significant at at $P \leq 0.05,0.01$, or 0.001 , respectively.

(Table 3). The Signature fertilizer treatment had the largest loss of all fertilizers from 2 DAT to 4DAT in the first run, and from 2 DAT to $7 \mathrm{DAT}$ in the second run. Isotek and Contec were usually intermediate in daily losses between Signature and the two Lesco fertilizers. Loss of the two Lesco fertilizers was very small in comparison to the other fertilizers tested and only occurred with the first mowing event of each run (Table 3 ).

A significant fertilizer $\times$ rate interaction was found to occur for most collection days in the K study (Table 3 ). Rate had the greatest effect on Signature loss during the first mowing of each run and was $7 \%$ to $8 \%$ greater at the lower K application rate. Other significant rate differences in loss for the other fertilizers were generally small $(<0.5 \%)$.

Total fertilizer granule loss for the Signature treatments were $\approx 22 \%$ at the lower K rate and $16 \%$ at the higher rate (Table 3 ). Total Isotek loss ranged from about $9 \%$ to $11 \%$ depending on run and rate. Like the Signature treatment, Isotek loss was significantly greater at the low $\mathrm{K}$ rate during the second run. Contec loss was unaffected by rate and ranged from $\approx 5 \%$ to $7.5 \%$ while total Lesco fertilizer losses were $<0.5 \%$ of the applied fertilizer.

Nitrogen fertilizer loss. Data from the two runs of the N study were pooled after Levene's test revealed homogeneity of variance for daily and total losses (Table 4). Significant differences did exist between fertilizers for daily and total losses (Table 4).

All $\mathrm{N}$ fertilizer treatments had the greatest amount of loss at 2 DAT with losses being $>30 \%$ for Nutralene, and $>40 \%$ each for Milorganite, IBDU, and Polyon (Table 4). Signature and Isotek losses were $\approx 13 \%$ and $7 \%$, respectively, and were quite comparable to the losses measured at 2 DAT in the $\mathrm{K}$ study (Table 3). N-Sure Pro loss was estimated to be $\approx 0.5 \%$ of the applied liquid fertilizer on 2 DAT.

Loss of each fertilizer, except N-Sure Pro, decreased considerably from the first (2 DAT) to second (3 DAT) mowing event (Table 4). However, IBDU and Polyon losses still exceeded $10 \%$ of applied fertilizer. All treatment losses continued to decline for the remainder of the study, but small amounts of every fertilizer except Signature were found in clippings at 9DAT. These final daily losses were usually $<0.5 \%$. Signature loss at 9 DAT was zero.

Total fertilizer loss due to mowing was large for Milorganite, IBDU, Polyon, and Nutralene with losses ranging from about $48 \%$ for Nutralene to nearly $75 \%$ for Polyon (Table 4). Signature and Isotek losses were $\approx 19 \%$ and $10 \%$, respectively, and were quite similar to the losses reported in the K study (Table 3). Total loss of N-Sure Pro was estimated to be only $1.89 \%$.

\section{Discussion}

Losses ranged from $<0.5 \%$ to almost $23 \%$ of the fertilizers used in the K study (Table 3 ) to over $75 \%$ for one of the granular $\mathrm{N}$ fertilizers tested (Table 4). The higher losses measured in the $\mathrm{N}$ fertilizer trial are presumably due to their higher degree of water insolubility (Table 2). Fertilizer loss and water insolubility rankings were nearly identical for the $\mathrm{N}$ fertilizer treatments. The two 6.4-mm irrigations used in this study were not effective in dissolving or moving these fertilizers into the turf canopy before the first mowing removed the fertilizer with the clippings (Table 4). The irrigation and mowing strategy used in this study was more effective in reducing the loss of Signature, Isotek, and, to a lesser extent, Nutralene. These $\mathrm{N}$ treatments had higher water-solubilities than Milorganite, IBDU, and Polyon (Table 2). N-Sure Pro, the liquid fertilizer, had very low losses in comparison to the granular $\mathrm{N}$ fertilizers because of its high water-solubility, as well as the fact that it had been sprayed onto turf foliage that was below the mower's height of cut. 
Table 4. Percentage of applied greens-grade N-containing fertilizer granules lost due to the mowing of a 'Pennlinks' creeping bentgrass putting green. Fertilizers were applied at a rate of $4.86 \mathrm{~g} \cdot \mathrm{m}^{-2} \mathrm{~N}$ on 30 June (Run 1) and 14 July 1999 (Run 2). Data from the two runs were pooled after Levene's test revealed homogeneity of variance between runs for daily and total loss data.

\begin{tabular}{|c|c|c|c|c|c|c|c|c|c|}
\hline \multirow[b]{2}{*}{ Fertilizer } & \multicolumn{9}{|c|}{ Days after treatment } \\
\hline & 2 & 3 & 4 & 5 & 6 & 7 & 8 & 9 & Total \\
\hline & ---- & --- & ---1 & $\%$ of app & d fertiliz & ost - - & --- & --- & ---1 \\
\hline Milorganite 6-2-0 & $41.46 b^{2}$ & $7.32 \mathrm{c}$ & $2.54 \mathrm{~d}$ & $1.89 \mathrm{~b}$ & $0.99 \mathrm{~b}$ & $0.61 \mathrm{~b}$ & $0.57 \mathrm{a}$ & $0.30 \mathrm{c}$ & $55.68 \mathrm{~b}$ \\
\hline IBDU $31-0-0$ & $47.34 \mathrm{ab}$ & $12.28 \mathrm{a}$ & $7.29 \mathrm{a}$ & $4.12 \mathrm{a}$ & $2.51 \mathrm{a}$ & $0.74 \mathrm{a}$ & $0.65 \mathrm{a}$ & $0.49 \mathrm{~b}$ & $75.42 \mathrm{a}$ \\
\hline Polyon $42-0-0$ & $50.67 \mathrm{a}$ & $10.16 \mathrm{ab}$ & $4.89 \mathrm{~b}$ & $2.14 \mathrm{~b}$ & $0.97 \mathrm{~b}$ & $0.65 \mathrm{~b}$ & $0.65 \mathrm{a}$ & $0.65 \mathrm{a}$ & $70.78 \mathrm{a}$ \\
\hline Nutralene $40-0-0$ & $31.05 \mathrm{c}$ & $8.57 \mathrm{bc}$ & $3.56 \mathrm{c}$ & $2.20 \mathrm{~b}$ & $1.05 \mathrm{~b}$ & $0.74 \mathrm{a}$ & $0.42 \mathrm{~b}$ & $0.42 \mathrm{~b}$ & $47.01 \mathrm{~b}$ \\
\hline UHS Signature $15-0-30$ & $13.65 \mathrm{~d}$ & $3.05 \mathrm{~d}$ & $1.03 \mathrm{e}$ & $0.84 \mathrm{c}$ & $0.39 \mathrm{c}$ & $0.24 \mathrm{c}$ & $0.08 \mathrm{c}$ & $0.00 \mathrm{~d}$ & $19.28 \mathrm{c}$ \\
\hline Lebanon Isotek 11-3-22 & $7.06 \mathrm{e}$ & $1.15 \mathrm{de}$ & $0.49 \mathrm{e}$ & $0.32 \mathrm{~d}$ & $0.23 \mathrm{c}$ & $0.11 \mathrm{c}$ & $0.04 \mathrm{c}$ & $0.06 \mathrm{~d}$ & $9.46 \mathrm{~d}$ \\
\hline N-Sure Pro $30-0-0$ & $0.48 \mathrm{f}$ & $0.43 \mathrm{e}$ & $0.18 \mathrm{e}$ & $0.20 \mathrm{~d}$ & $0.23 \mathrm{c}$ & $0.16 \mathrm{c}$ & $0.09 \mathrm{c}$ & $0.12 \mathrm{~d}$ & $1.89 \mathrm{e}$ \\
\hline
\end{tabular}

${ }^{\mathrm{z}}$ Percentage data arcsin transformed prior to statistical analysis. Mean separation down a column by LSD, $P \leq 0.05$. $\mathrm{n}=8$.

Potassium fertilizer loss seemed to be related to solubility, granule size, and bulk density (Tables 1 and 3). As an example of the influence of solubility on loss, Lebanon's Isotek, while being the coarsest fertilizer tested, had lower losses than the finer, but less soluble UHS Signature fertilizer (Table 1). UHS Signature was also a denser material than Isotek (Table 1), which could have contributed to slower dissolution under field irrigation conditions. Finer granule size could help to explain why the less soluble Contec fertilizer had lower loss than the coarser, but more soluble, Isotek fertilizer (Tables 1 and 3). Both of these fertilizers had similar bulk densities (Table 1). It can only be speculated that the difference in loss between Contec and Signature is due to the Signature fertilizer having a greater bulk density than Contec (Table 1). Both of these fertilizers had similar laboratory water-solubility, and Signature was finer than Contec. There was also a trend for the denser, more soluble Lesco 5-0-28 to have a higher loss than the less dense, lower solubility Lesco 12$0-22$. Overall, the combination of finer granule size and higher water solubility resulted in very low losses for the two Lesco fertilizers in comparison to the other fertilizers that were tested (Table 3).

Potassium application rate had very little affect on the percentage of applied fertilizer that was lost (Table 3). Fertilizer loss was greater on a weight basis (data not shown) at the higher $\mathrm{K}$ rate, but percentage of loss remained about the same. In those instances where rate did have an effect, the percentage recovered by the mower increased as the amount applied decreased.

The loss of some greens-grade fertilizers through mowing was significant, particularly for fertilizers with lower water solubility. Our irrigation and mowing regime, although typical of what a golf course superintendent might do following a fertilizer application, was not adequate in preventing the mower from picking up fertilizer. It appears that more water-soluble, finer granular fertilizers, as well as liquid fertilizers, have the lowest potential for being lost through routine mowing. Increased irrigation could probably help to reduce the loss of the more watersoluble fertilizers such as Signature, Isotek, Contec, and, to a certain extent, Nutralene. It would be useful if fertilizer manufacturers and turf researchers could make specific recommendations about how much irrigation water is required to minimize mowing loss. Currently, manufacturers make no recommendation about irrigation, or make recommendations to lightly irrigate (IMC Vigoro, Winter Haven, Fla.), apply a single 5-mm irrigation (The Scott's Co., Marysville, Ohio), or apply enough irrigation water to remove the fertilizer from the foliage (The Andersons, Maumee, Ohio). Better postfertilization irrigation recommendations could probably reduce the mowing loss of more water-soluble greens-grade fertilizers. However, a reduction in the loss of less soluble fertilizers will primarily be dependent on the use of finer particle sizes than those currently being used for putting greens if mowing and clipping collection is resumed soon after fertilizer application.

\section{Literature Cited}

Blake, G.R. 1980. Proposed standards and specifications for quality of sand for sand-soil-peat mixes. In: J.B. Beard (ed.). Proc. $3^{\text {rd }}$ Intl. Turfgrass Res. Conf., p. 195-203, Munich, Germany. 1113 July 1977. Intl. Turfgrass Soc., and ASA, CSSA, SSSA, Madison, Wis.

Beard,J.B. 1982. Turf Management for Golf Courses. Macmillan Publishing, New York.

Gomez, K.A., and A.A. Gomez. 1984. Statistical procedures for agricultural research, second addition. John Wiley and Sons, New York.

Mancino, C.F., and C.J. Hornstein. 1998. Effects of mowing on $\mathrm{N}$ loss from various $\mathrm{N}$ fertilizers. The Pennsylvania State Univ. Center for Turfgrass Science 1998 Annu. Res. Rpt.: 47-49.

Minitab Statistical Software. 2000. Release 12 for Windows 95 \& NT. State College, PA.

National Turfgrass Evaluation Program. 2000. National putting green bentgrass test. NTEP Progress Report No. 00-1. Beltsville, Md.

Ostmeyer, T. 1999. New management of new cultivars. Golf Course Mgt. 67(5):20-44.

Tabatabai, M.A. and J.M. Bremner. 1991. Automated instruments for determination of total carbon, nitrogen and sulfur in soils by combustion techniques, p. 261-286. In: K.A. Smith (ed.). Soil analysis: Modern instrumental techniques. $2^{\text {nd }}$ ed. Marcel Dekker, New York.

Woolhouse, A.R. 1973. An assessment of the effectiveness of a slow release nitrogen fertilizer on sports turf. J. Sports Turf Res. Inst. 49:8-20.

Woolhouse, A.R. 1974. Further assessment of the effectiveness of a slow release nitrogen fertilizer on sports turf. J. Sports Turf Res. Inst. 50:34-46.

SAS Institute. 1994. The SAS system for Windows. Release 6.10. SAS Inst., Cary, N.C.

U.S. Golf Association. 1993. USGA recommendations for a method of putting green construction. USGA Green Section Record (March/April): 133. 